\title{
Ruokinnan suunnittelu uudistuu - KarjaKompassi työvälineeksi
}

Juho Kyntäjä1) ja Marketta Rinne ${ }^{2)}$

1)ProAgria Keskusten Liitto, PL 251, 01301 Vantaa, etunimi.sukunimi@proagria.fi,

2) MTT (Maa-ja elintarviketalouden tutkimuskeskus), 31600 Jokioinen, etunimi.sukunimi@mtt.fi

\section{Tiivistelmä}

KarjaKompassi on uusi maitotilojen tuotannonhallinnan työväline, jolla seurataan ja suunnitellaan ruokintaa, tuotantoa ja sen taloutta. Se tuo jokaisen karjan tasolle ravitsemustutkimuksen viimeaikaiset edistysaskeleet lehmien syönnin ja maitotuotosvasteiden ennustamisessa ja antaa käyttäjälle mahdollisuuden valita uudella tavalla ruokinnan optimoinnin perusteet. Se myös yhdistää maitotilan toiminnan eri osa-alueet: rehuntuotannon, maidontuotannon ja talouden. KarjaKompassi on koko maitoalan laajan yhteistyön tulosta.

Asiasanat: KarjaKompassi, lypsylehmät, neuvonta, ruokinnansuunnittelu, syönti, tuotosvaste 


\section{Johdanto}

Maidontuotannon kannattavuus on asia, johon jokainen alalla työskentelevä joutuu paneutumaan uudella tavalla nyt, kun maidon tuottajahinta ja erilaisten tuotantopanosten hinnat vaihtelevat aikaisempaa nopeammin ja vapaammin. Hintasuhteista riippumatta on aina kannattavaa parantaa tuotannon fyysisillä mittareilla mitattavaa tehokkuutta ja tuottavuutta. ProAgria ja Valioryhmän meijerit ovat lähteneet kehittämään suomalaisen maidontuotannon tuottavuutta yhteisen Plus 20 -ohjelman avulla. Sen merkittävänä osana on KarjaKompassiksi nimetty ohjelmistokokonaisuus, joka valmistuessaan uudistaa tuotannon suunnittelun ja kustannusseurannan.

\section{KarjaKompassi -ohjelmisto}

KarjaKompassi on merkittävä tutkimus- ja kehitysprojekti, jolla Suomen taloudellisesti suurimman maatalouselinkeinon eli maidontuotannon hallinta paranee merkittävästi. Kotieläintutkimuksen meta-analyysit ovat tuottaneet uutta tietoa lypsylehmien syönnistä, rehuannoksen sulavuudesta ja tuotosvasteista, joita ruokinnansuunnittelussa hyödynnetään. Ohjelmisto toimii nettipohjaisesti jolloin tietojen kulku molempiin suuntiin ProAgrian rekistereissä tapahtuu on-line, millä saadaan merkittävää lisäarvoa palveluihin (vrt. Rinne ym. 2009).

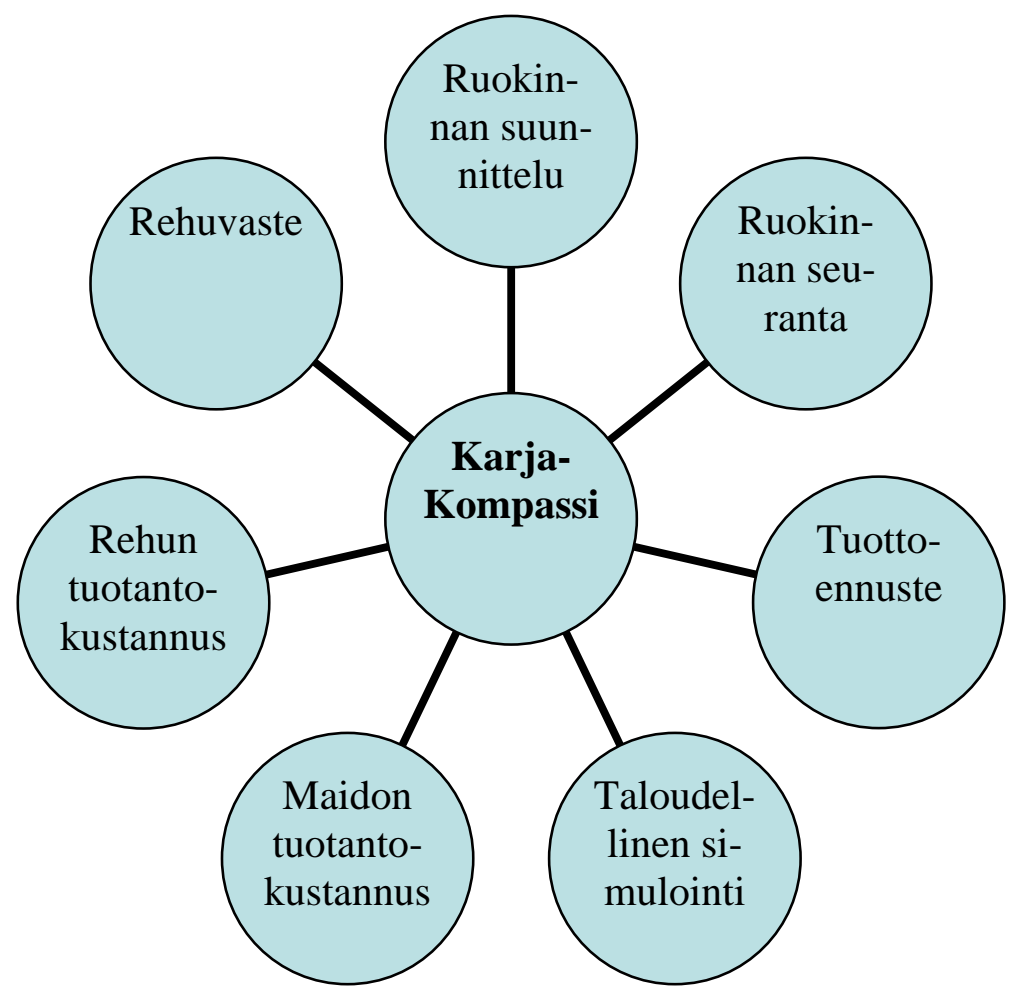

Kuva 1. KarjaKompassi yhdistää monien palvelujen tuottaman tiedon

KarjaKompassi kokoaa yhteen karjasta eri laskelmiin kerätyn tiedon ja sille laaditut suunnitelmat helposti käytettävään muotoon (Kuva 1). Nämä laskelmat ovat aina helposti saatavilla verkkopalvelussa, josta ne tarvittaessa saa käyttöönsä ProAgrian kehittämispalveluita tekevä asiantuntija tai yhtä lailla viljelijä itse.

KarjaKompassi ei kuitenkaan ole pelkkä ohjelmistohanke. Sen taustatiedoksi tarvitaan tutkimusta, jota MTT:ssa ja Helsingin Yliopistossa on tehty monia vuosia. Joihinkin erityiskysy-

myksiin tehdään hankkeen nimissä uutta tutkimusta. Näistä tutkimuksista kuulemme lisää seuraavissa esityksissä (Huhtanen ym. 2010, Nousiainen ym. 2010, Kokkonen ym. 2010). Ohjelmistohankkeen myötä saadaan tutkimuksen tulokset käytäntöön ja maidontuottajan hyödyksi, mm. uusi tieto rehujen syöntiin vaikuttavista tekijöistä ja ruokinnan tuotosvasteista. Tämä uusi tieto antaa mahdollisuuden parantaa tuotannon kannattavuutta merkittävästi.

KarjaKompassi pitää sisällään nautojen ruokinnansuunnitteluun sisältyvät palvelut ProAgriassa. Siihen sisältyvät Rehuvaste, ruokinnan seuranta, ruokinnansuunnittelu ja tuottoennuste. KarjaKompassin osioista jo nyt käytössä on Rehuvaste, jonka avulla voidaan simuloida ja vertailla erilaisten ruokintavaihtoehtojen tuotannollista ja taloudellista vaikutusta ja valita 
näin taloudellisin ehdotetuista ruokinnoista karjalle. Myös maidon tuotantokustannuslaskenta on jo uudistunut. Vuoden 2010 alussa on otettu käyttöön myös uudenlainen ruokinnan seurantatapa, jolla päästään arvioimaan ruokinnan onnistumista ja rehukustannuksia entisten jaksolaskelmien lisäksi myös päivittäisellä tasolla.

Vuoden 2010 lopulla saadaan käyttöön Ruokinnan suunnittelu, jota voi hyvällä syyllä pitää KarjaKompassin tärkeimpänä osiona. Sen myötä siirrymme optimoimaan ruokintaa sen antamien tuotosvasteiden perusteella, millä odotetaan olevan merkittävää vaikutusta rehukustannukseen ja sitä kautta myös maidon tuotantokustannukseen. Optimointiperusteeksi voi valita mahdollisimman ison maitotuoton ja rehukustannuksen erotuksen, mutta myös muita tuotantoon tai ympäristöön liittyviä tekijöitä karjanomistajan tarpeiden ja tavoitteiden mukaan.

Keväälle 2011 jäävät talouslaskelmien valmiit versiot sekä Tuottoennuste. Tuottoennuste on osio, joka käyttää hyödyksi lypsykarjan jalostusarvostelussa syntyvät laskennan sivutuotteet ja arvioi niiden perusteella kunkin lehmän tuotosta ja kannattavuutta 12 kk eteenpäin. Tuottoennusteella voi suunnitella maidontuotantoa myös pidemmälle ajalle, mistä on hyötyä erityisesti investointitilanteessa. Kotoisten rehujen ja maidon tuotantokustannuksen laskentaa yksinkertaistetaan ja virtaviivaistetaan. Kustannusten selvittäminen laskemalla on hyvin tärkeää, kun etsitään parempaa tuotannon kannattavuutta. Rehuntuotannon simulointi avaa uusia mahdollisuuksia kilpailukykyisempään ruokintaan (Rinne ym. 2010).

\section{KarjaKompassin teoreettinen perusta}

KarjaKompassin ruokinnansuunnittelu pohjautuu nykyisiin rehuarvoihimme eli rehujen energiapitoisuus ilmaistaan rehujen sulavuudesta johdettua muuntokelpoista energiaa käyttäen. Valkuaisarvoina käytetään pohjoismaisena yhteistyönä kehitettyä OIV-PVT-järjestelmää (ohutsuolesta imeytyvä valkuainen ja pötsin valkuaistase) kansallisin muunnoksin. Ruokinnansuunnittelu päädyttiin perustamaan nykyisiin rehuarvoihin, koska rehuarvojärjestelmien vertailuissa se on osoittautunut parhaaksi ja tarvittava rehuanalytiikka on käytettävissä (MTT 2006, Huhtanen 2010).

Osana KarjaKompassi-projektia yhdistettiin MTT:n ja Proagrian rehurekisterit, jolloin rehukirjaston ylläpidossa saadaan synergiahyötyjä ja rehuarvoihin tehtävät tarkennukset ovat ajantasaisesti KarjaKompassi-ohjelmiston käytössä. Samalla tarkennetaan mm. märehtijöiden valkuaisarvojen laskentaa (Huhtanen ym. 2010).

Lehmien ruokinnansuunnittelu KarjaKompassissa perustuu kuitenkin aivan uudenlaiseen lähestymistapaan, jossa liikkeelle lähdetään siitä, että rehuannoksen koostumus vaikuttaa lehmän syöntimäärään. Säilörehun ja väkirehun syönti-indeksien avulla arvioidaan vaikutukset toteutuvaan syöntiin (Huhtanen ym. 2007, 2008, Rinne ym. 2008). Ruokintatason ja rehuannoksen koostumuksen vaikutukset sulavuuteen arvioidaan laajasta aineistosta laskettuihin empiirisiin yhteyksiin perustuen (Nousiainen ym. 2009, Huhtanen ym. 2009, Nousiainen ym. 2010). Syönnin ja sulavuuden perusteella lehmien aineenvaihdunnan käyttöön tuleva ravintoaineiden määrä pystytään ennustamaan varsin tarkasti. Maitotuotos voidaan sitten ennustaa käyttäen laajasta ruokintakoeaineistosta laskettuja ravintoaineiden saantiin perustuvia tuotosvasteita (Huhtanen ym. 2008, Kokkonen ym. 2010).

Lehmien ruokinnansuunnittelun biologisten tekijöiden kvantitatiivisessa hallinnassa on siis päästy merkittävästi eteenpäin. KarjaKompassiin tulee myös monipuoliset ruokinnan taloudellisen ja biologisen optimoinnin mahdollisuudet pohjautuen Lypsikiksi nimettyyn optimointimalliin. Nyt pystytään ottamaan huomioon ruokinnan muutosten taloudelliset vaikutukset rahatuloihin maidon määrän ja koostumuksen muutosten kautta.

Ruokintaa voi optimoida myös esimerkiksi ravintoaineiden käytön tehokkuuden perusteella eli vaikka minimoida lantaan erittyvän typen ja fosforin määrää. Monipuoliset opti- 
mointimahdollisuudet ovat tulevaisuudessa entistäkin tärkeämpiä, koska tuotantopanosten ja tuotteiden hinnat jatkavat todennäköisesti nopeita muutoksiaan.

Lehmien ruokinta on vain yksi osa lypsykarjatilan monitahoista kokonaisuutta. KarjaKompassi nivoo ruokinnan entistä saumattomammin tilan muihin keskeisiin prosesseihin kuten rehuntuotantoon ja talouteen. Koko kehitystyön tavoitteena on maitotilojen entistä rationaalisempi toiminta, kun biologiset vaikutukset pystytään huomioimaan päätöksenteossa entistä tarkemmin. Tuloksena päätöksenteko helpottuu, työ on mielekkäämpää ja tilan taloudellinen tulos paranee.

\section{KarjaKompassin tekijät ja käyttö}

KarjaKompassi -hankkeen rahoittavat Suomen Meijeriyhdistyksen jäsenmeijerit, ProAgria ja Teknologian Kehittämiskeskus TEKES. Työpanoksellaan mukana ovat Maatalouden Laskentakeskus, MTT, SLU, Bitcomp Oy, Valio Oy, Helsingin Yliopisto ja Työtehoseura.

KarjaKompassia voivat sen valmistuttua käyttää kaikki maitotilojen kanssa työskentelevät ProAgrian asiantuntijat sekä rahoitukseen osallistuneiden meijerien neuvontahenkilöstö ja tutkimuslaitokset. Viljelijät voivat ostaa käyttöoikeuksia ohjelmiston itsenäiseen käyttöön. Rehuvaste on jo nyt tilattavissa käyttöön ProAgrian verkkosivuilla.

\section{Kirjallisuus}

MTT. 2006. Rehutaulukot ja ruokintasuositukset -verkkopalvelu. Viitattu 10.11.2009. www.mtt.fi/rehutaulukot Huhtanen, P., Rinne, M. \& Nousiainen, J. 2007. Evaluation of the factors affecting silage intake of dairy cows: a revision of the relative silage dry-matter intake index. Animal 1: 758-770.

Huhtanen, P., Rinne, M. \& Nousiainen, J. 2008. Evaluation of concentrate factors affecting silage intake of dairy cows: a development of the relative total diet intake index. Animal 2: 942-935.

Huhtanen, P., Nousiainen, J. \& Rinne, M. 2008. Lypsylehmien rehuannoksen taloudellinen optimointi tuotosvasteiden perusteella. Julkaisussa: Maataloustieteen Päivät 2008 [verkkojulkaisu]. Suomen Maataloustieteellisen Seuran tiedotteita no 23. Toim. Anneli Hopponen. Julkaistu 9.1.2008. Saatavilla Internetissä: http://www.smts.fi/mpol2008/index tiedostot/Esitelmat/es075.pdf

Huhtanen, P. ym. 2010. Lypsylehmien valkuaisarvojärjestelmä (OIV-PVT) uudistuu. Maataloustieteen Päivät 2010.

Kokkonen, T., Mäntysaari, P. \& Huhtanen, P. 2010. Lypsylehmän energiataseen mallintaminen.

Maataloustieteen Päivät 2010. Saatavilla Intrenetissä: www.smts.fi.

Nousiainen, J., P. Huhtanen, and M. Rinne. 2009. A meta-analysis of feed digestion in dairy cows. 1. The effect of forage and concentrate factors on total diet digestibility. J. Dairy Sci. 92: 5019-530.

Huhtanen, P., M. Rinne, and J. Nousiainen. 2009. A meta-analysis of feed digestion in dairy cows. 2. The effects of feeding level and diet composition on digestibility. J. Dairy Sci. 92:5031-5042.

Nousiainen, J., Rinne, M. \& Huhtanen, P. 2010. Rehuannoksen koostumus ja ruokintataso vaikuttavat lypsylehmien rehuannoksen sulavuuteen. Maataloustieteen Päivät 2010.

Rinne, M., Huhtanen, P. \& Nousiainen, J. 2008. Säilörehun ja koko rehuannoksen syönti-indeksit auttavat lypsylehmien ruokinnan suunnittelussa. Julkaisussa: Maataloustieteen Päivät 2008 [verkkojulkaisu]. Suomen Maataloustieteellisen Seuran tiedotteita no 23. Toim. Anneli Hopponen. Julkaistu 9.1.2008. Saatavilla Internetissä: http://www.smts.fi/mpol2008/index_tiedostot/Esitelmat/es086.pdf

Rinne, M., Huhtanen, P., Nousiainen, J., Kyntäjä, J., Rinta-Kiikka, S. 2009. KarjaKompassi näyttää ruokinnan suunnan. Maaseudun Tiede 1/2009 (9.3.2009): 16.

Rinne, M., Pitkänen, T., Nyholm, L., Nousiainen, J. \& Huhtanen, P. 2010. Alkukesän nurmikasvuston sulavuuden ja sadon määrän mallit nurmirehuntuotannon hallintaan. Maataloustieteen Päivät 2010. 